\title{
Hajj Service Management to Increase Pilgrim Satisfaction from Gorontalo
}

\author{
Kasmad Mile, Asna Aneta, Rauf A. Hatu, Zuchri Abdussamad \\ Postgraduate Program in the State University of Gorontalo \\ Program of Study in Administration
}

\begin{abstract}
The research aims to analyze and describe hajj service management to increase pilgrim satisfaction from Gorontalo. The research method was the mix method, a method that combined two methods, the qualitative and quantitative. Data were collected by questionnaire, interview, observation, and Focus Group Discussion (FGD) techniques. Informants were 14 hajj officials and 30 respondents consisting of 2014-2018 pilgrims. The findings were: First, hajj service management in Gorontalo was started by: 1) doing an open and systematic hajj official recruitment online, 2) performing hajj services, 3) monitoring and evaluating hajj services by studying field cases, and 4) conducting follow-up to improve and optimize the services; second, factors determining successful hajj services were: 1) management/hajj official commitment, 2) budget/human resource supports, 3) leadership commitment, and 4) pilgrim competence, to prevent any dependency showed by the pilgrims to each other, and third, average hajj satisfaction was $86.06 \%$, consisting of: 1) services at Antara Hajj Embarkation, 2) administrative services, 3) health services, and 4) hajj transportation services. Besides, the evidence argued that when the pilgrims were in Mecca, the mo'duola (social solidarity) culture began to be abandoned and disappear due to their selfishness.
\end{abstract}

Keywords: hajj service management, pilgrim satisfaction

DOI: $10.7176 / \mathrm{PPAR} / 9-6-09$

Publication date:June $30^{\text {th }} 2019$

\section{Introduction}

Hajj implementation is one of the national duties and responsibilities of the government. However, they seem to abandon the duties and responsibilities and are assumed not to be as serious and professional as suggested by the Law. The assumption is proven by the fact that there are always problematic issues in hajj process, although it is continuously improved from year to year. There are always pregnant pilgrim that pass the test, late flight schedule, inappropriate accommodation, increasing hajj cost, canceled pilgrim schedule, and even starved pilgrims in 2006. Even, there are rumors spreading that the government may take their own profits from the hajj implementation (General Director of the Ministry of Religious Affairs, 2006:1). There are many programs that are not in accordance with the hajj implementation standards and new, additional costs that are not listed in the hajj expense regulation; such as pilgrim accommodation management, transportation, and catering.

Those issues, especially in domestic (Indonesia) and international (Saudi Arabia) services shall be routinely evaluated to improve hajj implementation quality. Regular hajj implementation by the government is one of the public services that shall be always evaluated.

To give qualified services, we shall make attempts oriented to satisfying consumers. Satisfying services are actually an evaluation of selected alternative products. The products shall be in accordance or above the client expectation; while disappointing services appear when reality does not meet the expectation. Service is closely related to consumer satisfaction, as the main goal of excellent service is to meet the consumer satisfaction.

The main key to succeed hajj service and thus increase pilgrim satisfaction is strongly affected by the management competence as the main actor to serve the pilgrims. Martin (1994:24) believes that competence includes function, task, skill, ability, or personal traits of someone. Additionally, budget/human resource supports and leadership commitment determine hajj services as well.

As a hajj implementation, the government of Gorontalo is obliged to do optimum services including assistance and protection by providing administration, accommodation, transportation, consumption, health, safety, and supporting infrastructure services needed by the pilgrims, as clarified by the legislation (Local Regulation of Gorontalo Number 5 Year 2013 Article 4). 
Success hajj service in Gorontalo is determined by the satisfaction level of pilgrims receiving services. To performing duties and functions of Hajj Operation Committee well, good management is definitely required, because management is an activity to regulate the use of human resources to achieve the organization goal effectively.

Ministry of Religious Affairs of Gorontaly is frequently facing a dilemma, that even though they have made various efforts to manage hajj well, there are always mistakes and errors, hence affecting the management and administration. The government has made various regulations; such as the Law, president regulation, and minister regulation to regulate all related factors, easing the hajj implementation. Additionally, they have to face different obstacles every year, too.

According to our preliminary research, there are other complaints frequently proposed, i.e. the time taken to make a hajj passport and the distance between the immigration office and several office of the Ministry of Religious Affairs. It is an obligation of any involved parties to give an optimum service system, so that the government, or the Ministry of Religious Affairs will be able to implement the system to meet the pilgrim demand.

Observed in the ratio comparing the annual number of hajj officials and that of pilgrims (1:75), we believe that they will be exhausted to manage the pilgrims, possibly creating errors and mistakes in the field. In consequent, they will also give minimum services.

Therefore, the research becomes essential, since it may provide a description of hajj service management to improve pilgrim satisfaction. The satisfaction is supported by factors affecting a success hajj services, namely management competence, budget/human resource support, and leadership commitment. By that, we can identify the level of pilgrim satisfaction on hajj services in Gorontalo, either from Antara Embarkation of Gorontalo, hajj administration service, hajj health service, or hajj transportation service.

\section{Literary Review}

\section{Hajj Service Management}

Hajj service management covers three aspects, hajj official and management recruitment, service implementation, monitoring, and evaluation.

Recruitment constitutes a process to determine and draw competent applicants to work. The aim is to accept applicant as many as possible in accordance with the requirements, enabling the company to select the best qualified candidates (Rivai and Sagala, 2013:148-150). Ministry of Religious Affairs of the Republic of Indonesia (2010:122) stipulates the recruiting system for Hajj Operation Committee (Panitia Penyelenggara Ibadah Haji, PPIH) that shall be done from the level of the Ministry of Religious Affairs of Regency or City as well as the Provincial and Central Regional Office of the Ministry of Religious Affairs. After being selected, they are trained in order to be professional, competent, and service-spirited. The recruitment is done online, openly, and systematically by applying the android-based Computer Assisted Test (CAT) system. Successful hajj implementation relies on the hajj official professionalism. Therefore, to produce competent, fully committed, loyal, pious officials, an accurate need analysis on service and position, tight administration and health selection, a competence test shall be done (Ministry of Religious Affairs of the Republic of Indonesia, 2013:5).

Kathi and Cooper, in Silalahi (2015) confirm that when services given are qualified and can satisfy the society, the government will have a positive public image. Contrastively, when the government does not provide qualified and satisfying public services, society will give the, negative public feelings or cynic. Fair and responsible public service generates public trust as the base to establish a good governance (Asna Aneta, 2017).

Gaspersz (2003) conveys that service quality shall concerns of punctuality, accuracy, politeness, hospitality, accountability, completeness, and easiness to obtain the service.

To ensure if the service has been well implemented, monitoring and evaluation are important. Casely and Kumar (1987) declares monitoring as a continuant evaluation on project activity functions in the context of implementation schedule and the use of project input by the target group in the context of design expectation.

Azwar (2000) explains that based on the scope, evaluation can be divided into four groups: a) Input evaluation includes the use of various resources, either fund, energy, or infrastructure, b) Evaluation emphasizes the program implementation, whether or not it has been in accordance with the planning, organization, and implementation, c) Output evaluation is performed when the program has been finished (summative evaluation). It aims to measure the output and results, and d) Impact evaluation includes the effect of the implemented program. 
Several activities that have to be prepared for monitoring and evaluation stages are: 1) Determining a team consisting of program stakeholders to monitor the evaluation, especially target group of the program or project and determining aspects that shall be monitored and evaluated (activities, regions, and others), 2) Determining indicators referring to the indicator measurement tool that has been determined during the program implementation stage to monitor and evaluate institutions, 3) Creating a data collection system, 4) Making data tabulation, 5) Analyzing data, and 6) Making a report of monitoring and evaluation results. Based on the study and comparison between the monitoring and evaluation, hajj service shall be implemented in accordance with the expectation, and hence fair service can be realized.

\section{Factors Determining a Success Hajj Service Management}

There are three aspects determining a successful hajj service management that are: 1) management competence, budget/human resource supports, and leadership commitment.

Some experts, in Kadji (2015) has proposed their arguments regarding competence as follows: Kadampully (2001:118) defines competence as the most basic individual acting on factors affecting a successful work in a certain situation. H.A.S. Munir (2006:62) mentions that by sufficient ability and skill, a task/work may be well implemented and meet the demand of all parties and the management itself. Management competence shall be supported by budget/human resources. Dana allocation for each construction sector, including hajj implementation is annually stipulated in the State Budget. In the provincial and regency/city levels, budget mostly comes from the fund granted by the central government through the local-own source revenue stipulated in the Local Government Budget. Local Regulation of Gorontalo Number 5 Year 2013 stipulates that local operational cost, hereinafter referred to as operational cost is cost from the Local Government Budget to fund parts of or the entire hajj implementation service process (Article 1 Paragraph 20). Hajj cost budget is from: 1) Direct cost that is paid by the pilgrims to the bank account of the Ministry of Religious Affairs via BPS BPIH (Bank Penerima Setoran Biaya Penyelenggaran Ibadah Haji, Bank Accepting the Fee Deposit for Hajj implementation); 2) Indirect cost from the benefit value of the early fee deposit paid by pilgrims; and 3) State budget (Part 3 Article 13).

In the Local Regulation Number 5 Year 2013, the Government of Gorontalo has given budget supports, i.e. 1) Reducing the cost that has to be paid by regular pilgrims; 2) Funding transportation service by using the Local Government Budget of Gorontalo (Article 12 Paragraph 8) including: a) Returned flight ticket and airport tax (from the domicile area to the Embarkation and from the Debarkation to the domicile area), b) Insurance, c) Security and airport porter, d) Baggage service, e) Airport bus apron, and f) Snacks and food; 3) Funding pilgrim assistances by using the Local Government Budget of Gorontalo; and 4) Funding pilgrim consumption by using the Local Government Budget of Gorontalo.

Human resources is the main drive force. Nawawi, in Gaol (2014:44) describes human resources as those working and functioned as an organization/company asset that are countable (quantitative) and a potency that motivates the organization. Excellent human resources have working ethics required to provide satisfying public service.

The decree of the Ministry of Administrative and Bureaucratic Reform Number 25 Year 2002 on the fundamental values of work culture mentions two of the work culture, namely commitment and leadership. Toto Tasmara (2002:85) indicates that commitment (derived from the Latin language: committere, to connect, entrust the state of being obligated or emotionally impelled) is firm binding faith (aqad) that binds someone's heart and directs his behavior to his believed path. Fiedler, in Kadji (2015:100) proposes that "in the very favorable conditions in which the leader has power, informal backing, and a relatively well-structured, task, the group is ready to directed, and the group expects to be told what to do". In this dimension, one of the advantageous conditions is that when a leader has an authority, informal support, well-structured task, and staffs or employees that are ready to be led. Therefore, a leader has to be able to create a conducive and pleasing atmosphere for his/her employees. Additionally, a leader shall be able to make a create work climate for all employees, and thus they can conduct their own responsibilities and duties.

\section{Pilgrim Satisfaction}

Kotler (2000:36) states that "satisfaction is a person's feelings of pleasure or disapointment resulting fromcomparing a product's percieved performance (or outcome) in relation to his or her expectations". Satisfaction is the difference felt between reality and expectation.

Services at Antara Hajj Embarkation include services of: 1) Accommodation, 2) Consumption, 3) Customs, 4) Immigration, 5) Quarantine, 6) City check-in, and 7) Other services required during pilgrimage (Article 3 of the Regulation of the Ministry of Religious Affairs Number 3 Year 2013). Besides, Antara 
Embarkation accommodation is also provided for physical recovery of exhausted pilgrims (reservation) and practical assistance of the manasik of hajj that is directly practiced in accordance with facilities provided by Antara Embarkation. The practice is aimed as repetition and enforcement, since the pilgrims usually have practiced the manasik of hajj in their own regions.

Gorontalo has provided land transportation services from the hajj dormitory of Gorontalo Antara Embarkation to Djalaludin Airport and from Djalaludin Airport to hajj and air transportation services from Djalaludin Airport to the Embarkation airport and from the Debarkation airport to Djalaludin Airport Gorontalo (Local Regulation 2013, Article 12 Paragraph 1). Consumption is given to pilgrims when they are at Antara Embarkation and Debarkation Airport (Article 14). Final health checking for the pilgrims is regulated by Article 16 Paragraph 1-b). Moreover, customs, immigration, and Harbor Health Office services are given by related institutions at Antara Hajj Embarkation (Article 16 Paragraph 2).

In the middle of increasingly prime and qualified hajj services, as the main information provider, Siskohat (Sistem Informasi dan Komputerisasi Haji Terpadu, Integrated Hajj Information and Computerization System) does contribute a lot for KBIHs (Kelompok Bimbingan Ibadah Haji, Assisted Hajj Group) in Indonesia (Ministry of Religious Affairs, 2014:13). By Siskohat, information about pilgrim position and status from registration, departure, operation in Saudi Arabia, to returning can be easily and quickly obtained (Ministry of Religious Affairs, 2014:17).

Siskohat provides a great contribution for hajj and umrah services in Indonesia. It has several functions, i.e. 1) Registering and saving both pilgrim and official database, 2) Processing passport and visa documents, 3) Publishing Administrative Pilgrimage Documents (DAPIH, Dokumen Administrasi Perjalanan Haji), 4) Paying BPIH online by BPS BPIH, 5) Implementing BPIH accounting system, 6) Processing cancelation, 7) Arranging flight manifestation and groups (fleets), 8) Monitoring flight on-time performance (OTP), 9) Monitoring pilgrim health, and 10) Monitoring hajj operation in Indonesia and Saudi Arabia (Siskohat team, 2017).

Additionally, each pilgrim was given health services, as stipulated by the Local Government of Gorntalo Number 5 Year 2013 Article 15 that commands: 1) Pilgrim health service shall include first aid action, prevention, maintenance, checking, and treatment (Paragraph 1); 2) Health services shall be conducted by the Pilgrimage Regional Health Teams coordinated with the Indonesian Hajj Health Offcier started from the preparation stage in the hajj dormitory, Antara Hajj Embarkation, Embarkation, hajj implementation in Saudi Arabia, Debarkation, Antara Hajj Embarkation, and hajj dormitory (Paragraph 2).

Health services for pilgrims at the Embarkation are started when the pilgrims enter the hajj dormitory and gather in the hall for health document completeness checking (BKJH, ICV, medicine, and medical equipment brought by the pilgrims and pregnancy test for women of child-bearing age). All pilgrims will stay at dormitories for their pilgrimage preparation. When there are pilgrims with unwell condition, they will be brought to a clinic for further examination. Given there is an indication of more severe illness, medical workers will do laboratory examination or any other supporting examination. The pilgrims will be treated and cured before then returned to their dormitory and gather with other pilgrims. Meanwhile, those that cannot be cured at the Embarkation clinic and need another further action will be referred to Hajj Referral Hospital (LKJ of the Ministry of Health, 2016:17).

To make pilgrims more convenient, by the Law Number 13 Year 2008 on Hajj Management, the Government has regulated a general description of transportation service as follows: 1) Pilgrim transportation service to Saudi Arabia and their returning to Indonesia Embarkation was the Minister accountability. The Minister shall be coordinated with another minister taking responsibilities in transport and 2) Appointment of hajj transportation implementation is performed by ministers by concerning of safety, security, convenience, and efficiency aspects.

\section{Research Methods}

Research methods applied were the mixed method: combining two methods, i.e. qualitative and quantitative methods in research. The research aimed to obtain better understanding and elaborating the discussion (Creswell, 2010:304-3011). Besides, the mixed method is intended to confirm the research finding validity. Susan Staiback (1988) in Sugiyono (2014:400) suggested that each method could actually be applied to complement another method.

Sugiyono (2014:400) argued that qualitative and quantitative methods could be combined but not simultaneously used. In this research, the qualitative method constituted a case study describing hajj service 
management and factors determining a successful hajj service. Moreover, the quantitative method was in forms of survey to explain pilgrim satisfaction towards hajj services. In addition to that, it applied the percentage formulae.

Data were collected by using questionnaire, observation, interview, and Focus Group Discussion techniques and analyzed by using the interactive analysis method consisting of data reduction, data presentation, data verification, and conclusion drawing. Meanwhile, informants involved 14 hajj officials and 30 pilgrims from 2014-2018.

\section{Research Findings}

\section{Hajj Service Management}

One of the attempts to realize hajj services based on justice, transparency, and accountability with nonprofit principles was hajj official recruitment. Gary Desler $(2011: 126)$ argued that "employee recruiting means finding and or attracting applicants for the employer's open positions".

Referring to interview results, hajj official recruitment had been done online since 2014; while since 2018, the recruitment had been performed by using an android-based Computer Assisted Test (CAT) system. By this system, participants directly answered problems presented on a computer monitor or android mobile phone. The system was necessary to select professional hajj officials. "Hajj official candidates fill the data correctly and completely then upload the required files that have been scanned via online. After being justified to pass our administration selection, they shall perform Computer Assisted Test (CAT). According to the CAT result, hajj official candidates will be tested again to measure their understanding and experiences by interviews and practices, enhancing their accountability principle covering their competence and integrity. In addition to that, we have to ensure that the selected candidates have been in accordance with our requirements" (interview, 5/11/2018). "By the CAT system, hajj official candidates may directly answer the problems presented on the computer monitor layer. They may also use android-based smartphones and directly answer the problems there. Online recruitment by the CAT system was one of the methods to select professional officials" (interview, 5/11/2018). By that, we assumed that hajj official recruitment had been openly and systematically conducted, from the administrative selection stage, Computer Assisted Test (CAT), interview, and practice. The selected officials should be professional, competent, and service-spirited and thus could meet the pilgrim expectation to be able to perform their obligation well and achieve the title of hajj mabrur.

Hajj services were focused on services at Antara Hajj Embarkation, hajj administration services, health services, and transportation services.

"Antara Embarkation services included accommodation, consumption, customs, immigrations, quarantine, health, city check-in, and practical manasik of hajj practice assistance that was directly implemented in accordance with facilities available at Antara Embarkation Dormitory" (interview, 8/1/2018).

Online connectivity-based technology and communication and real-time information provision encouraged the Ministry of Religious Affairs to always give services and the mostly updated information accessible by all pilgrims.

Services by Siskohat eased pilgrims to conduct all activities related to hajj service system; such as hajj registration, portion number issuance, departure year information accessible wherever and whenever on the official website of the Ministry of Religious Affairs.

"Hajj officials of the Ministry of Gorontalo clarified that registration database saved in Siskohat might also be functioned to ease and accelerate document preparation, accelerate fleet pre-manifestation, ensure the issuance of the summons for entering the hajj dormitory at the Embarkation, ease BPIH reporting accounting and living cost, become as one of the references to make pilgrim identity, provide accommodation and consumption at the Embarkation or in Saudi Arabia, and as a control/crosscheck tool to filter various pilgrim data misuse" (interview, 5/11/2018.

Hajj passport services at the Ministry of Religious Affairs of Gorontalo were collectively done by proposing passport application coordinated by the Ministry. The proposal was performed through the Immigration Office.

Stages of passport application proposal were: 1) Pilgrims came to the Immigration Office by bringing: citizen identification card copy, family registers, birth certificate, and BPIH receipt, 2) Pilgrims filled the Application for Immigration Documents 11 by filling the name column by at least three syllables, 3) Pilgrims 
should have a recommendation letter from the Ministry of Religious Affairs, and 4) Pilgrims took their biometric pictures, were interviewed, and signed their passport (interview, 4/23/2018).

The head of the hajj division of the Ministry of Religious Affairs of Gorontalo confirmed, "In making of passport, pilgrims do not have to spend money anymore, as their needs have been fulfilled by their optimization deposit of IDR360,000/pilgrim. Therefore, once the pilgrim passport had been published by the Immigration Office, it would be delivered to the officials of the Ministry of Religious Affairs of Gorontalo that than later was delivered to the Central Ministry of Religious Affairs" (interview, 5/11/2018).

Siskohat database had the data variable related to the demand of pilgrim health service, including highrisk pilgrim data and results of pilgrim health examination, so that they could assist health workers to perform medical services during operational period of hajj at the Embarkation or in Saudi Arabia. Additionally, Siskohat had also an application providing data and information for health services related to outpatient pilgrims, inpatient pilgrims, referred pilgrims, and dead pilgrims. The data were used to conduct an analysis on the level of health safety for pilgrims.

In terms of health services, an official of the Health Office of Gorontalo declared, "To maximize health services, the Health Office of Gorontalo does activities integrated with health promotion program, family health socialization, environmental health, social nutrition, physical fitness assistance, non-communicable disease control, traditional health, spiritual health, and surveillance" (interview, 5/12/2018).

As the hajj implementation, the government was obliged to manage and give maximum transportation services to pilgrims by concerning of security, safety, convenience, and efficiency aspects. According to the interview result with the committee of hajj transportation service implementation 2018, "The local government provides local transportation cost subsidy for pilgrims from Gorontalo that will be paid by using the State Budget, from Djalaludin airport to Makassar Embarkation Airport by a special transportation (charter)" (interview, $5 / 14 / 2018$ ). Land transportation used by pilgrims had been prepared by the local government and the Ministry of the Religious Affairs of Gorontalo, started from pilgrim deliverance to Djalaludin Airport by using a special bus (charter) equipped by AC, speakers, and convenient seats" (interview, 5/14/2018).

In hajj implementation by the Ministry of the Religious Affairs of Gorontalo, the head of hajj and umrah of the regional office of the Ministry of Religious Affairs of Gorontalo did both monitoring and evaluation activities. Besides, all aspects were also be monitored by the government institutions professionals in their fields. Meanwhile, the Health Office and Department of Transportation directly monitored catering health and appropriateness and transportation appropriateness respectively, so were other aspects. Those aspects were monitored to be directly reported to the head of hajj and umrah division. The last stage that should be performed was to make a conclusion as a final report that was later regarded as a new standard for future hajj implementation.

\section{Factors Determining a Successful Hajj Service in Gorontalo}

In principles, a successful hajj implementation depended on hajj official professionalism. To create competent, committed, and loyal officials that believed in Islamic values, we required to select professional hajj officials by a good, open, and systematical selection process, from the administration selection, Computer Assisted Test (CAT), interview, and practice stages. Ministry of Religious Affairs should prepare professional and competent hajj officials that strongly committed to implement their duties and responsibilities.

The head of hajj and umrah division at the regional office of the Ministry of Religious Affairs of Gorontalo conveyed that: 1) Hajj assistants were civil servants/state civil apparatuses at the Ministry of Religious Affairs by work experience of at least five years that had been on pilgrimage, had graduated from a bachelor degree in Islam, were able to recite Koran well, understood hajj implementation regulation, and were able to speak Arabic and/or English and 2) Manasik of hajj assistant had an assistant certificate issued by the Ministry of Religious Affairs of the Republic of Indonesia by education and trainings (interview, 8/1/2018).

Such complex hajj implementation required supports to provide optimum services for pilgrims, including man and money. The services might be realized by supports of budget and professional human resources.

Head of hajj and umrah at the regional office of the Ministry of Religious Affairs of Gorontalo explained, "The government of Gorontalo has allocated annual budget for hajj implementation, as stipulated by the State Budget. For manasik of hajj, they allocated IDR399,000/pilgrim. In addition to that, they provided local transportation cost subsidy, namely returned flight ticket and airport tax (from the domicile area to the Embarkation, and from the Debarkation to the domicile area)" (interview, 8/1/2018). 
The head of hajj and umrah division at the Ministry of Religious Affairs of Gorontalo added, "At the hajj dormitory, all pilgrims were given both accommodation and consumption, passport and visa, identity bracelet, a series of medical equipment, and living cost of SAR1,500" (interview, 5/11/2018).

Hajj officials at the Office of the Ministry of Religious Affairs of Gorontalo, on behalf of NH mentioned that for pilgrims from Gorontalo, the local government of Gorontalo gave annual allowance. Each of them would obtain SAR200 (interview, 5/11/2018). Once the commitment was strongly held, hajj implementation might be well implemented. Hajj implementation should be based on justice, professionalism, and accountability principles as well as non-profit principles and aimed to provide assistance, service, and protection for all pilgrims, enabling them to complete their hajj in accordance with sharia.

\section{Pilgrim Satisfaction on Hajj Services in Gorontalo}

Hajj satisfaction was observed from four types of services given, that were services at Antara Hajj Embarkation of Gorontalo, hajj administration services, hajj health services, and hajj transportation services.

Results of questionnaire on Antara Hajj Embarkation of Gorontalo indicated that 56.67\%, 33.33\%, $8.33 \%, 0.56 \%$, and $1.11 \%$ of pilgrims respectively were highly satisfied, satisfied, less satisfied, unsatisfied, and highly unsatisfied, proving that most pilgrims were satisfied by services provided at Antara Hajj Embarkation. We assumed that if the number of satisfied respondents was equal to the ideal assumption, i.e. highly satisfied $=5 \times 6$ $\times 30=900$, the percentage would be $100 \%$. However, the result of questionnaire revealed the total score of 799 , and hence proposed the pilgrim satisfaction level of $88.78 \%$. It had belonged to a good category ranging from $81-$ $100 \%$. In conclusion, service quality provided at the Embarkation was excellent (SB, sangat baik).

In terms of hajj administration services, results of questionnaire stated that $52.22 \%, 38.89 \%, 8.33 \%$, and $0.56 \%$ of pilgrims respectively were highly satisfied, satisfied, less satisfied, and unsatisfied, suggesting that most pilgrims were satisfied by the services. The total score of 797, arguing that the pilgrim satisfaction level was $88.56 \%$. It had belonged to a good category ranging from $81-100 \%$. To sum up, administration service quality was excellent (SB, sangat baik).

Regarding hajj health services, results of questionnaire clarified that $42.78 \%, 46.11 \%, 10.56 \%$, and $0.56 \%$ of pilgrims respectively were highly satisfied, satisfied, less satisfied, and unsatisfied, confirming that most pilgrims were satisfied by the services. We assumed that if the number of satisfied respondents gave similar responses to the ideal assumption that was highly satisfied $=5 \times 6 \times 30=900$, the percentage would be $100 \%$. Nevertheless, the result of questionnaire conveyed the total score of 775 , declaring that the pilgrim satisfaction level was $86.11 \%$. It had belonged to a good category ranging from $81-100 \%$. In conclusion, service quality provided at the Embarkation was excellent (SB, sangat baik).

Furthermore, results of questionnaire clarified that in terms of hajj transportation services, $30.56 \%$, $48.33 \%, 17.22 \%$, and $2.22 \%$ of pilgrims were highly satisfied, satisfied, less satisfied, and unsatisfied respectively. The percentages defined that most pilgrims were satisfied by the services. We assumed that when the number of satisfied respondents gave similar responses to the ideal assumption that was highly satisfied $=5 \times 6 \times 30=900$ ), the percentage would be $100 \%$. The result of questionnaire conveyed the total score of 727 , describing that the pilgrim satisfaction level was $80.78 \%$. It had belonged to a good category ranging from $70-80 \%$. Therefore, transportation service quality provided at the Embarkation was good $(\mathrm{B}$, baik).

The entire services could satisfy pilgrims from Gorontalo.

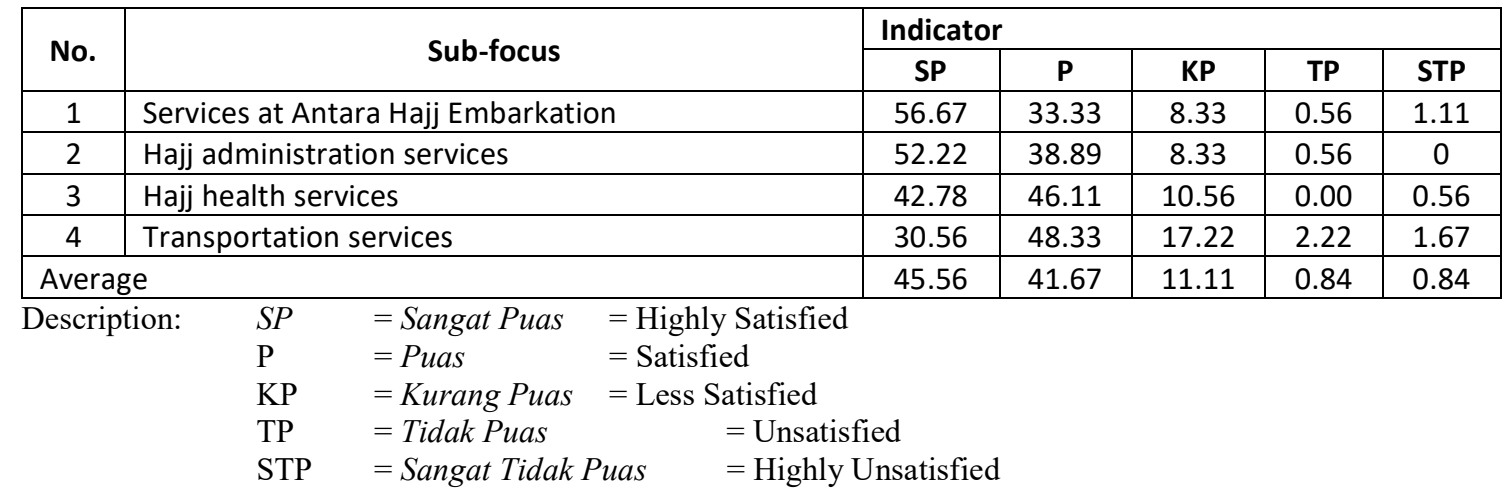


Data described by the above table indicated that most pilgrims were satisfied by hajj services in Gorontalo. Details are mentioned in this chart:

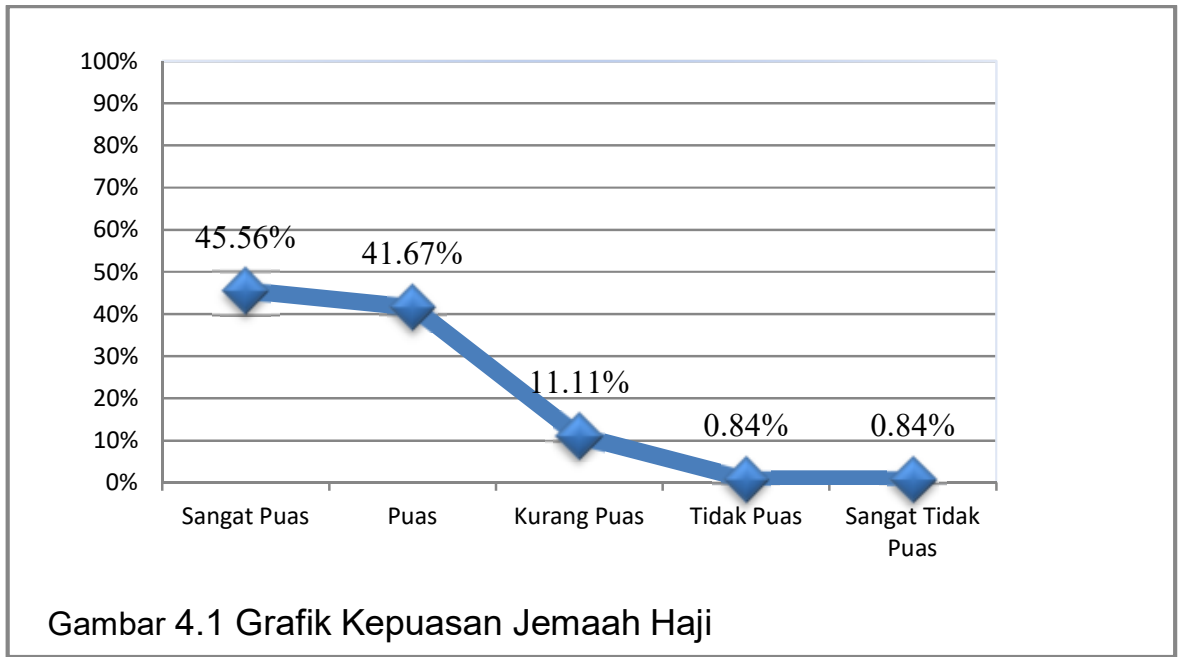

Referring to Chart 4.1, in general, four sub-focuses had satisfied pilgrims from Gorontalo, as suggested by the percentage of satisfied pilgrims $(45.56 \%+41.67 \%=87.23 \%)$. However, there were still unsatisfied pilgrims $(11.11 \%+0.84 \%+0.84 \%=12.79 \%)$.

\section{Research Finding Framework}

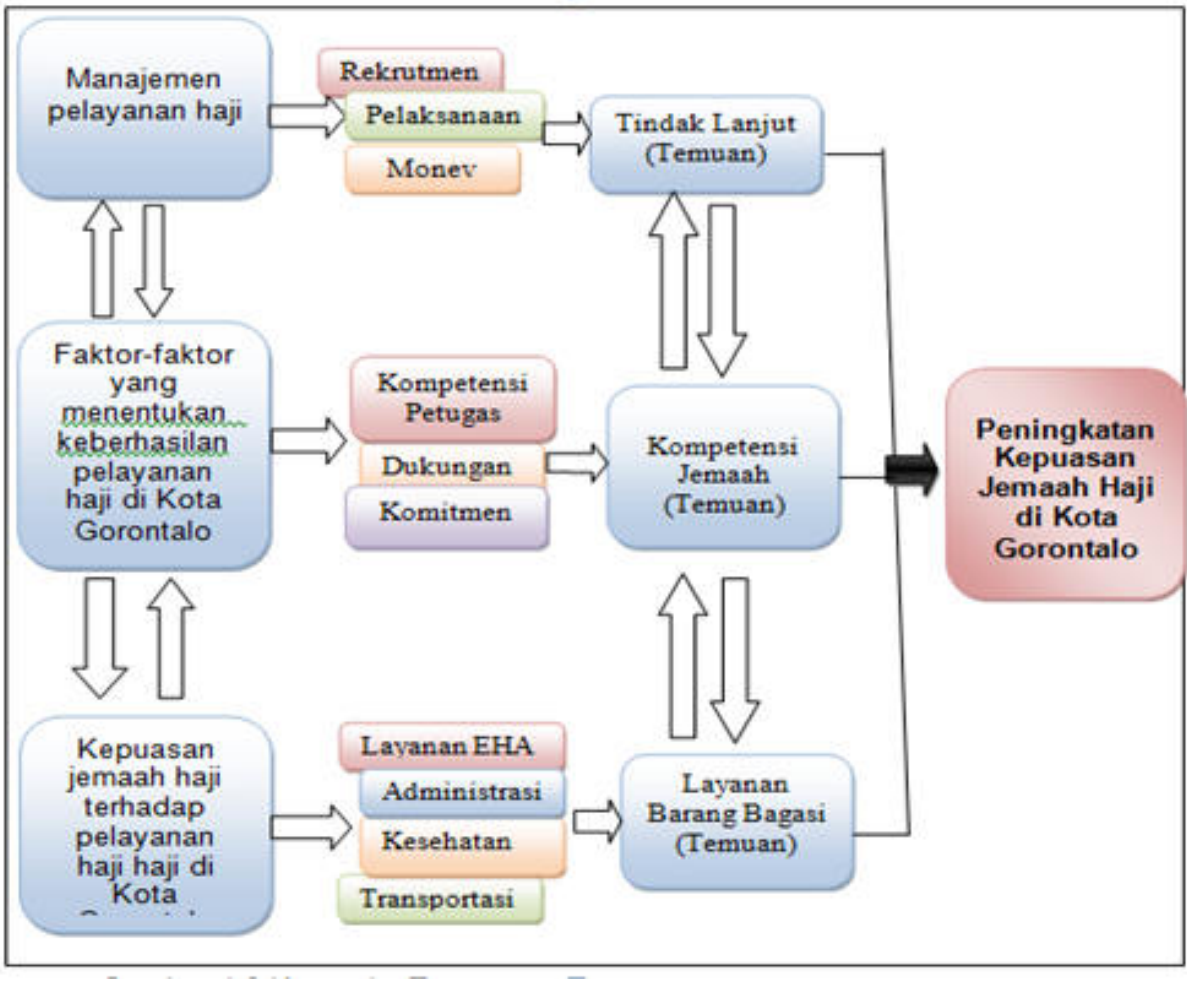

Based on the finding framework, there are several matters to be emphasized:

- Any follow-up shall be done, especially that regarding hajj official recruitment, hajj service implementation, and monitoring and evaluation to improve the services. In addition to that, well-performed and highly 
integrated hajj officials shall be given a reward; while the badly-performed ones can be given punishment in accordance with the applicable regulation, hence giving a moral lesson for them.

- $\quad$ Pilgrim competence, knowledge, and understanding on Siskohat are important to enable them to access Siskohat by themselves, easing them to do hajj registration and database fulfillment and accelerating document preparation. Siskohat can be constantly monitored and controlled in real time. Additionally, pilgrims shall have both knowledge and understanding on hajj, preventing any dependency on each other or on the hajj officials. The levels of pilgrim knowledge on hajj processes and pilgrim independence on performing hajj highly determine a successful hajj implementation. Besides, interpersonal competences of pilgrims are also a determinant factor.

- Baggage services have to be improved, too. Airlines stipulate a tight regulations regarding baggage, especially in terms of over baggage. To satisfy pilgrims, the government shall add the amount of baggage service, or free baggage service for over baggage.

\section{Conclusion}

1. Hajj service management determines pilgrim satisfaction in Gorontalo. The management includes online hajj official recruitment openly and systematically held, from the administration selection stage, Computer Assisted Test (CAT), interview, and practice, effective and efficient hajj service implementation, and continuant monitoring and evaluation for service improvement.

2. Hajj service management will make hajj services more effective, once the recruitment, implementation, monitoring, and evaluation are followed up. A series of activities shall be initiated by problem identification to generate the solution. Besides, reward and punishment shall also be given to hajj officials.

3. Hajj official competences, either professional, social, or personality are the factors determining a successful hajj service that satisfies pilgrims from Gorontalo. The factors shall be accompanied by budget, human resources, and leadership commitment in the implementation of the Law and Local Regulation of Gorontalo on Hajj Implementation.

4. Factors determining a successful hajj service will more satisfy pilgrims, when the hajj official competence, budget/human resource support, and leadership commitment are combined with the pilgrim competence factor. Therefore, their knowledge and understanding on Siskohat and Islamic teachings regarding hajj are strongly required.

5. A general percentage of pilgrim satisfaction from Gorontalo was $86.06 \%$ consisting of:
a. Services at Antara Hajj Embarkation 88.78\%
b. Administration service $88.67 \%$
c. Health service $86.11 \%$
d. Transportation service $80.78 \%$

6. Level of pilgrim satisfaction from Gorontalo will be maximum when services at EHA, administration service, health service, and transportation service are added by baggage service.

\section{Suggestions}

1. Ministry of Religious Affairs of Gorontalo shall be consistent regarding hajj service management, started from hajj official recruitment, service implementation, and hajj service monitoring and evaluation. 
2. To optimize hajj service management and satisfy pilgrims from Gorontalo, the government shall implement one more stage, namely follow-up that shall be integrated with hajj service recruitment, implementation, and evaluation.

3. A successful hajj service shall be realized by emphasizing determinant factors that are hajj official competence, budget/human resource support, and leadership commitment to satisfy pilgrims from Gorontalo.

4. To optimize hajj services, pilgrim competence factors are also important, as each pilgrim has different levels of knowledge and understanding.

5. Level of pilgrim satisfaction shall be continuously improved.

6. Hajj officials are suggested to concern of baggage services and enable pilgrims to understand the regulation concerning baggage capacity and those concerning allowable and disallowable stuffs to bring.

\section{References}

A.S. Moenir, 2000, Manajemen Pelayanan Umum di Indonesa, Jakarta: Bumi Aksara.

Aneta, Asna et al., 2017, Kualitas Pelayanan Publik di Kantor Sistem Administrasi Manunggal Satu Atap (SAMSAT) Kota Gorontalo, State University of Gorontalo.

----------, 2017, Mewujudkan Good Governance Melalui Standar Pelayanan Minimal (SPM) Dinas Kesehatan Kota Gorontalo. State University of Gorontalo.

Abdussamad, Zuchri, 2017, Kompetensi Aparat dalam Pelayanan Publik, Ministry of Law and Human Rights of the Republic of Indonesia.

Bowman, C., 1990, The Essence of Strategic Management Englewood Cliffs, New Jersey, Pretince Hall. Buchari, Zainun. 2000. Manajemen dan Motivasi. Jakarta: Balai Aksara.

Covey, S.R, 1993, Principles Contered Leadrship, Franklin, Covey Co.

Dwiyanto, Agus, 2008, Mewujudkan Good Governance Melalui Pelayanan Publik. UGM Press, Yogyakarta. -----------, 2010, Manajemen Pelayanan Publik: Peduli, Inklusif, dan Kolaboratif. UGM Press, Yogyakarta. Fandy Tjiptono, 2008, Service Management, Yogyakarta: Andi.

Frederickson, H, George, 1984. Administrasi Negara Baru (New Public Administration). Translated by Al Ghoze, Jakarta: LP3ES.

Frederickson, H.G and D.K. Hart. 1984. The Public Service and the Patriotism of Bevolence. Public Administration Review.

Gaspersz, Vincent, 2003. Manajemen Bisnis Total-total Quality Management. Penerbit PT. Gramedia Pustaka Utama, Jakarta.

Gray, S., J., and Roberts, C. B,. 1989. Voluntary Information Disclosure and the British Multinatinals: Corporate Perceptions of Costs and Benefits.

Kadji, Yuliyanto, 2008, Implementasi Kebijakan dalam Perspektif Realitas, Tulungagung, Cahaya Abadi.

-------, 2015, Formulasi dan Implementasi Kebijakan Publik, Gorontalo, UNG Press.

Martin, S. 1994. Industrial Economics: Economic Analysis and Public Policy, $2^{\text {nd }}$ Edition. Macmillan Publishing Company: New York.

Tjiptono, Fandy, 2008, Service Management, Yogyakarta: Andi.

Ministry of Religious Affairs of the Republic of Indonesia, Standarisasi Pusat Informasi Haji, Jakarta, Director General for Guidance of the Islamic Community and Hajj Guidance. 2005.

-------------, Haji dari Masa ke Masa, Jakarta, Director General for Guidance of the Islamic Community and Hajj Guidance. 2006.

------------, Bunga Rampai Perhajian, Jakarta, Director General for Guidance of the Islamic Community and Hajj Guidance, 1998.

Instruction of the Directorate General of Civil Aviation, Number INST 009 Year 2017 on Hajj Air Transport Organization 2017.

Ministry of Religious Affairs of the Republic of Indonesia, Intisari Langkah-langkah Pembenahan Haji, Jakarta, Directorate General of Hajj and Umrah Organization, 2010.

Ministry of Religious Affairs of the Republic of Indonesia, Realita Haji. Jakarta, Directorate General of Hajj and Umrah Organization, 2014 